\title{
Organoleptic evaluation of germinated fenugreek seed flour incorporated recipes: Chapatti and Idli
}

HEMLATA PANDEY AND PRATIMA AWASTHI

Received: 24.09.2013; Revised: 07.03.2015; Accepted: 18.03.2015

See end of the paper for authors' affiliations HEMLATA PANDEY Department of Foods and Nutrition, G.B. Pant University of Agriculture and Technology, PANTNAGAR (UTTARAKHAND) INDIA
ABSTRACT : Fenugreek contains balance of both soluble ( $\beta$-glucan) and insoluble fibre. The objective of the present study was development of high fibre germinated fenugreek seed flour and its incorporation in some homemade recipes viz, chapatti and $i d l i$. Nutritional quality of germinated fenugreek seed flour was evaluated. Nutritional analysis revealed that moisture $(5.5 \%)$, protein $(41.2 \%)$, crude fat $(3.7 \%)$ soluble fibre $(11.3 \%)$ and insoluble fibre (19.9\%) content were higher whereas fat $(3.7 \%)$ content was low in germinated fenugreek seed flour. Sensory evaluation showed that chapatti was acceptable up to 20 per cent level of incorporation, whereas, idli was acceptable up to 30 per cent level of incorporation by panelists.

KEY WORDS: Fenugreek, Insoluble fibre, Idli, Chapatti, Sensory evaluation

- HOW TO CITE THIS PAPER : Pandey, Hemlata and Awasthi, Pratima (2015). Organoleptic evaluation of germinated fenugreek seed flour incorporated recipes: Chapatti and Idli. Asian J. Home Sci., 10 (1) : 41-44. 